\title{
Effect of muscle-fiber type on glycogenin-1 gene expression and its relationship with the glycolytic potential and $\mathrm{pH}$ of pork
}

\author{
S.-H. Zhang ${ }^{1}$, L. Zhu ${ }^{1}$, Z.-H. Wu' ${ }^{1}$, Y. Zhang ${ }^{2}$, G.-Q. Tang ${ }^{1}$, Y.-Z. Jiang ${ }^{1}$, \\ M.-Z. Li ${ }^{1}$, L. Bai ${ }^{1}$ and X.-W. Li ${ }^{1}$ \\ ${ }^{1}$ College of Animal Science \& Technology, Sichuan Agricultural University, \\ Ya'an, China \\ ${ }^{2}$ Department of Animal Science, Xichang College, Xichang, China \\ Corresponding authors: X.-W. Li / L. Zhu \\ E-mail: lixuewei9125@126.com / zhuli7508@163.com
}

Genet. Mol. Res. 12 (3): 3383-3390 (2013)

Received December 12, 2012

Accepted April 15, 2013

Published September 4, 2013

DOI http://dx.doi.org/10.4238/2013.September.4.4

\begin{abstract}
This study analyzed the effect of muscle-fiber type composition on glycogenin-1 (GYG) gene expression and its impact on $\mathrm{pH}$. The longissimus dorsi (LD) muscle contains more type IIB fibers $(75.10 \%)$ than does the psoas major (PM) muscle $(41.58 \%)$, while the PM has more type I (3.65 vs $0.94 \%)$, type IIA (34.15 vs $10.63 \%)$, and type IIX (20.62 vs 13.33\%) fibers. Compared with PM, glycolytic potential (GP), $\mathrm{pH}_{45 \text { min }}$, and $\Delta \mathrm{pH}$ from 45 min to $24 \mathrm{~h}$ post-mortem were all relatively higher in LD. Glycogen metabolites (lactate and GP) were negatively correlated with $\mathrm{pH}_{24 \mathrm{~h}}$ and positively correlated with $\Delta \mathrm{pH}$. Expression of GYG was generally higher in LD. GYG expression was positively correlated with glycogen metabolite (lactate and GP) content and $\Delta \mathrm{pH}$, and was negatively correlated with $\mathrm{pH}_{24 \mathrm{~h}}$. These data confirm that the muscle-fiber type and GP have significant effects on ultimate $\mathrm{pH}$ and $\mathrm{pH}$ decline, and suggest that expression of GYG in muscles is related to the metabolism of glycogen and may impact GP, $\Delta \mathrm{pH}$, and ultimate $\mathrm{pH}$. High expression of GYG was associated with a high
\end{abstract}


glycogen content, large $\mathrm{pH}$ decline, and low ultimate $\mathrm{pH}$ in muscles post-mortem.

Key words: Pig; Glycogenin-1; Muscle-fiber type; Glycolytic potential; Myosin heavy chains

\section{INTRODUCTION}

Muscle is the most important part of the livestock carcass, and determines its economic value. Previous studies have indicated that muscle fiber characteristics may affect postmortem changes that occur during the conversion of muscle to meat, which can ultimately affect many traits related to meat quality (Henckel et al., 1997; Choe et al., 2008; Lee et al., 2012). In mammals, most skeletal muscles consist of a mixture of muscle fiber types. Generally, based on the differential expression of isoforms of myosin heavy chains (MyHCs), the pork skeletal muscles consist of 4 types of muscle fibers: type I, type IIA, type IIB, and type IIX (Tanabe et al., 1999). Type I is a slow aerobic metabolism muscle fiber, which contains relatively more mitochondria and cytochromes and has low glycogen content. Type I muscle is also known as slow muscle fiber or red muscle fiber. Type IIA is a fast aerobic metabolism muscle fiber, which contains relatively more glycogen and some myosin. Type IIB is a fast glycolytic muscle fiber, which contains relatively less mitochondria and cytochromes and has high glycogen content. Type IIB muscle is also known as white muscle fiber or fast muscle fiber (Estrade et al., 1993; Tanabe et al., 1999). Type IIX is pink in appearance and its features are intermediate between types IIA and IIB.

Post-mortem $\mathrm{pH}$ is a large determinant of overall pork quality impacting its waterholding capacity, color, shelf life, texture, and functional properties of the meat (Fernandez and Tornberg, 1991; Boler et al., 2010). The decline in post-mortem pH from physiological levels to the ultimate $\mathrm{pH}$, reached $8-24 \mathrm{~h}$ post-mortem, is a reflection of biochemical changes occurring in the muscle, and is largely dependent on muscle glycogen content at the time of slaughter (Lawrie, 1966). As glycogen content increases, often estimated post-mortem by glycolytic potential, ultimate $\mathrm{pH}$ declines. However, there is a threshold at which further increases in glycolytic potential do not result in lowering of the ultimate $\mathrm{pH}$ (Bendall, 1973; Fernandez et al., 1992). Furthermore, several studies have shown a relationship between increased glycolytic potential and poorer meat quality, including paler, softer pork with poor water-holding capacity (Enfält et al., 1997; Hamilton et al., 2003).

Glycogenin-1 (GYG) is the protein core of glycogen (Smythe et al., 1990) and serves as an autocatalytic protein substrate for glycogen synthase (Alonso et al., 1995). Therefore, the number of GYG molecules available within the skeletal muscle dictates the number of glycogen particles available and hence the amount of glycogen that can be stored (Alonso et al., 1995). The expression of GYG may be the rate-limiting step of glycogen synthesis and may be more important than the activity of glycogen synthase (Alonso et al., 1995).

As glycogen content at the time of slaughter is an important determinant of post-mortem $\mathrm{pH}$, which in turn has a large impact on meat quality, and as glycogen content may depend on the presence and activity of GYG, the impact of muscle-fiber type on GYG expression and the effect of the GYG content of post-mortem muscles on glycolytic potential and $\mathrm{pH}$ decline were investigated in this study. 


\section{MATERIAL AND METHODS}

The experimental protocol was approved by the Animal Care and Ethics Committee of Sichuan Agricultural University, China.

\section{Animals and treatments}

Seventy-five market weight commercial barrows $(103.5 \pm 8.4 \mathrm{~kg})$ were slaughtered for this study. These pigs were standard halothane-free Duroc x (Landrace x Yorkshire) breeds and raised under uniform conditions to slaughter weight at the research pig farm of Sichuan Agricultural University. From $24 \mathrm{~h}$ prior to harvest, pigs were only allowed to have free access to water. On the day of harvest, all pigs were harvested according to humane, standard commercial procedures (Xiao et al., 1999).

\section{Muscle sampling and pH measurement}

\section{Samples for RNA extraction}

Two 70-mg muscle samples were collected as soon as possible post-mortem from the core of the longissimus dorsi muscle (LD, between the tenth and the last rib) and the psoas major muscle (PM), on the left side of the carcass. Muscle samples were immediately frozen in liquid nitrogen and subsequently stored at $-80^{\circ} \mathrm{C}$ until use in $\mathrm{MyHC}$ and $\mathrm{GYG}$ expression analyses.

\section{Samples for glycolytic potential (GP) analysis}

Each pig was sampled once at $45 \mathrm{~min}$ and $24 \mathrm{~h}$ after exsanguination. At each time point, a 6-g muscle sample was collected from the core of the LD and from the PM, on the left side of the carcass. Muscle samples were divided into two 3-g samples for chemical analysis at both sampling times. All samples were obtained from a previously unexposed area of tissue $(>1 \mathrm{~cm}$ from any cut surface) and were handled so as to minimize exposure to air and purge loss. Samples were immediately frozen in liquid nitrogen and subsequently stored at $-80^{\circ} \mathrm{C}$.

The carcasses of slaughtered pigs were kept in $4^{\circ} \mathrm{C}$ coolers for $24 \mathrm{~h}$. The $\mathrm{pH}$ and temperature of the intact muscle of the carcass were measured using a $\mathrm{pH}$ Star Probe with a glass electrode (SFK Technologies Inc., Cedar Rapids, IA, USA) on the cut surface of each section at $45 \mathrm{~min}\left(\mathrm{pH}_{45 \mathrm{~min}}\right)$ and $24 \mathrm{~h}\left(\mathrm{pH}_{24 \mathrm{~h}}\right)$ post-mortem. The difference in the $\mathrm{pH}$ value between these 2 time points was defined as $\Delta \mathrm{pH}\left(\Delta \mathrm{pH}=\mathrm{pH}_{45 \min }-\mathrm{pH}_{24}\right)$.

\section{GP}

Muscle samples were assayed for GP according to methods described in Hartschuh et al. (2002), except that concentrations were determined in comparison to standard curves of lactate and glucose. Glucose assays were performed with a coupled enzymatic assay kit (hexokinase and glucose-6-phosphate dehydrogenase; Sigma-Aldrich, St. Louis, MO, USA). Lactate content was measured using an enzyme assay, including lactate dehydrogenase (Sig- 
ma-Aldrich). Both assays measured the conversion of $\mathrm{NAD}^{+}$to NADH using a plate reader (Bio-Stack Ready, BIO-TEK Instruments Inc., Winooski, VT, USA) at $340 \mathrm{~nm}$. All results are reported as micromole per gram $(\mu \mathrm{mol} / \mathrm{g})$ wet muscle tissue. The concentrations of glucose6-phophate and glucose were not independently determined but were included in the glycogen determination, and the GP was calculated using the equation: GP $=2 \times($ glycogen + glucose + glucose-6-phosphate) + lactate (Monin and Sellier, 1985; Hambrecht et al., 2005).

\section{Gene expression}

Total RNA was prepared by disrupting tissues in TRIzol reagent (Invitrogen, Carlsbad, CA, USA) with a TissueLyzer (Qiagen, Valencia, CA, USA), following manufacturer instructions. One microgram of RNA was treated with DNAase before reverse transcription into cDNA (Quantitect Reverse Transcription kit, Qiagen). Expression of type I, IIA, IIB, and IIX MyHC isoforms, and expressions of GYG and $\beta$-actin were measured by Taqman real-time reverse transcriptase-polymerase chain reaction (RT-PCR) normalized to glyceraldehyde-3-phophate dehydrogenase. The Taqman primer/probe sets for all genes examined were obtained from Applied Biosystems (Foster City, CA, USA). The sequences of primers for type I, IIA, IIB, IIX, TOP2B, and TBP, were designed by Tanabe et al. (1999). The sequences of primers for glycogenin and $\beta$-actin were designed by Ylä-Ajos et al. (2007). Data are reported as the change in the cycle threshold $(\Delta \mathrm{Ct})$ values (Ct of GYG minus $\mathrm{Ct}$ of $\beta$-actin). Increased $\Delta \mathrm{Ct}$ is reflective of reduced expression.

\section{Statistical analysis}

All data were analyzed with SAS (SAS 9.2, SAS Inst. Inc., Cary, NC, USA). The MIXED procedure was used when analyzing the effect of muscle type and sampling time on GP, lactate, and $\mathrm{pH}$. The model included the fixed effects of muscle type, sampling time, and the interaction between muscle type and sampling time, and the identity of the individual animal was used as a random term. The model for analysis of the types I, IIA, IIB, and IIX MyHC isoforms on GYG expression included only muscle type as a fixed factor. The REG procedure was used to analyze the relationship among GP, lactate, $\mathrm{pH}$, and GYG expression. Least square means were evaluated using the PDIFF and STDERR options in SAS. Differences were considered to be significant when $\mathrm{P}<0.05$.

\section{RESULTS}

\section{Composition of muscle fiber types}

According to the expression ratio of MyHCs mRNA, significant differences were observed in the composition of muscle fiber types between the 2 muscles (Table 1). Fast-type $\mathrm{MyHC}$ isoforms were dominant in the porcine LD and more slow-type MyHC isoforms were present in the PM muscle. The LD muscle contains a significantly higher proportion of type IIB muscle fibers than does the PM (75.10 vs 41.58\%), whereas the PM has a higher proportion of type I (3.65 vs 0.94\%), type IIA (34.15 vs 10.63\%), and type IIX (20.62 vs 13.33\%) muscle fibers than does the LD. 


Table 1. Expression ratio of myosin heavy chains mRNA of longissimus dorsi and psoas major $(\mathrm{N}=75$; least
squares means $\pm \mathrm{SE})$.
\begin{tabular}{lcccc}
\hline Muscle & I & IIA & IIX & IIB \\
\hline Longissimus dorsi & $0.94 \%^{\mathrm{B}}$ & $10.63 \%^{\mathrm{B}}$ & $13.33 \%^{\mathrm{b}}$ & $75.10^{\mathrm{A}}$ \\
Psoas major & $3.65 \%^{\mathrm{A}}$ & $34.15 \%^{\mathrm{A}}$ & $20.62 \%^{\mathrm{a}}$ & $41.58 \%^{\mathrm{B}}$ \\
\hline
\end{tabular}

Within a column, least squares means with different lowercase superscript letters differ significantly at $\mathrm{P}<0.05$, those bearing different capital superscript letters differ significantly at $\mathrm{P}<0.01$.

\section{Effect of muscle and sampling time on glycogen metabolites and pH}

The LD had higher GP and lactate contents $24 \mathrm{~h}$ post-mortem $(\mathrm{P}<0.05)$ compared to the PM (Table 2). In addition, the LD had more energy reserves (GP, lactate) at both sampling times.

Table 2. Glycolytic potential, lactate concentration ( $\mu \mathrm{mol} / \mathrm{g}$ wet muscle), and $\mathrm{pH}$ in longissimus dorsi and psoas
major muscles.
\begin{tabular}{lccrc}
\hline Muscle & Sampling time & Lactate & $\mathrm{GP}$ & $\mathrm{pH}$ \\
\hline LD & $45 \mathrm{~min}$ & $86.79 \pm 17.14^{\mathrm{bc}}$ & $104.60 \pm 12.71^{\mathrm{bc}}$ & $6.27 \pm 0.30^{\mathrm{a}}$ \\
& $24 \mathrm{~h}$ & $99.76 \pm 17.91^{\mathrm{a}}$ & $117.00 \pm 13.75^{\mathrm{a}}$ & $5.67 \pm 0.11^{\mathrm{c}}$ \\
PM & $45 \mathrm{~min}$ & $80.46 \pm 12.14^{\mathrm{c}}$ & $95.86 \pm 11.63^{\mathrm{c}}$ & $5.88 \pm 0.18^{\mathrm{b}}$ \\
& $24 \mathrm{~h}$ & $92.61 \pm 13.13^{\mathrm{b}}$ & $107.08 \pm 13.98^{\mathrm{b}}$ & $5.72 \pm 0.34^{\mathrm{bc}}$ \\
\hline
\end{tabular}

Means within columns with different superscript letters differ significantly $(\mathrm{P}<0.05) . \mathrm{GP}=$ glycolytic potential $(\mathrm{GP}$ $=2 \mathrm{x}$ [glycogen + glucose + glucose-6-phosphate $)+$ lactate $] . \mathrm{LD}=$ longissimus dorsi; $\mathrm{PM}=$ psoas major.

With respect to $\mathrm{pH}$, there was a significant interaction effect between muscles and sampling time (Table 2). Specifically, the LD had higher $\mathrm{pH}$ at $45 \mathrm{~min}$ post-mortem and lower $\mathrm{pH}$ at $24 \mathrm{~h}$ post-mortem, and the difference was pronounced $(\mathrm{P}<0.05)$. The $\mathrm{pH}$ of the $\mathrm{PM}$ declined quickly in the first 45 min post-mortem, and the $\mathrm{pH}$ value at 45 min post-mortem was significantly lower than that of the $\mathrm{LD}(\mathrm{P}<0.05)$. The $\mathrm{pH}$ value, however, did not change significantly from 45 min to $24 \mathrm{~h}$ post-mortem in the $\mathrm{PM}(\mathrm{P}>0.05)$.

\section{Correlations between glycogen metabolites and $\mathrm{pH}$}

In both the LD and PM, lactate and GP showed significantly negative correlation coefficients with the ultimate $\mathrm{pH}$ value, and significantly positive correlation coefficients with $\Delta \mathrm{pH}$ (Table 3). The GP at 45 min post-mortem was negatively correlated with $\mathrm{pH}_{24 \mathrm{~h}}$. As a deduced estimation of energy reserves derived from the combination of glucose and lactate concentrations, GP at 45 min post-mortem showed the highest negative correlation with $\mathrm{pH}_{24 \mathrm{~h}}(\mathrm{r}=-0.77$, $\mathrm{P}<0.001)$ and a significant positive correlation with $\Delta \mathrm{pH}(\mathrm{r}=0.72, \mathrm{P}<0.001)$ in the LD. These results indicate that the low $\mathrm{pH}_{24 \mathrm{~h}}$ and $\mathrm{pH}$ decline post-mortem were correlated with the glycogenolysis process. High GP values in the muscle resulted in low $\mathrm{pH}_{24 \mathrm{~h}}$ and a greater decrease in $\mathrm{pH}$.

\section{GYG expression and correlations with glycogen metabolites and pH}

At 45 min post-mortem, the transcription level of the housekeeping gene $\beta$-actin was similar in the 2 muscles $(\mathrm{P}>0.05)$, but the GYG $\Delta \mathrm{Ct}$ of the LD was lower than that of the PM 
$(-0.2$ vs $1.1, \mathrm{P}<0.05)$, which indicated that transcription of the GYG gene was significantly higher in the LD than in the PM $(\mathrm{P}<0.05)$. The correlation coefficients between GYG expression and the glycogen metabolites (lactate and GP), $\mathrm{pH}$, and $\Delta \mathrm{pH}$ are listed in Table 4. It should be noted that because increased $\Delta \mathrm{Ct}$ is related to decreased gene expression, negative correlations with $\Delta \mathrm{Ct}$ indicate positive correlations with gene expression. GYG expression at 45 min post-mortem was significantly positively correlated with glycogen metabolite concentrations (lactate and GP) and $\Delta \mathrm{pH}$, and negatively correlated with $\mathrm{pH}$ at $24 \mathrm{~h}$ post-mortem, but was not correlated with $\mathrm{pH}$ at 45 min post-mortem in either muscle. In the LD, GYG expression showed its highest positive correlation with $\mathrm{GP}$ at $24 \mathrm{~h}$ post-mortem $(\mathrm{r}=0.59, \mathrm{P}<$ 0.01 ). These results indicate that increased expression of GYG was associated with increased glycogen metabolite concentrations and decreased ultimate $\mathrm{pH}$ values.

\begin{tabular}{|c|c|c|c|c|c|}
\hline \multirow[t]{2}{*}{ Muscle } & \multirow[t]{2}{*}{ Traits } & \multicolumn{2}{|c|}{45 min post-mortem } & \multicolumn{2}{|c|}{$24 \mathrm{~h}$ post-mortem } \\
\hline & & Lactate & GP & Lactate & GP \\
\hline \multirow[t]{2}{*}{ LD } & $\mathrm{pH}_{24 \mathrm{~b}}$ & $-0.73 * *$ & $-0.77 * *$ & $-0.48 *$ & $-0.61 * *$ \\
\hline & $\Delta \mathrm{pH}$ & $0.68 * *$ & $0.72 * *$ & $0.45^{*}$ & $0.56^{*}$ \\
\hline \multirow[t]{2}{*}{ PM } & $\mathrm{pH}_{24 \mathrm{~h}}$ & $-0.39^{*}$ & $-0.45^{*}$ & $-0.39^{*}$ & $-0.50^{* *}$ \\
\hline & $\Delta \mathrm{pH}^{24 \mathrm{~h}}$ & $0.70 * *$ & $0.72 * *$ & $-0.68 * *$ & $-0.74 * *$ \\
\hline
\end{tabular}

*Significant at $\mathrm{P}<0.05$. ${ }^{*}$ Significant at $\mathrm{P}<0.01 . \mathrm{pH}_{24 \mathrm{~h}}=\mathrm{pH}$ at $24 \mathrm{~h}$ post-mortem. For abbreviations, see legend to Table 2.

\begin{tabular}{|c|c|c|c|c|c|c|c|}
\hline \multirow[t]{2}{*}{ Muscle } & \multicolumn{3}{|c|}{45 min post-mortem } & \multicolumn{3}{|c|}{$24 \mathrm{~h}$ post-mortem } & \multirow[t]{2}{*}{$\Delta \mathrm{pH}$} \\
\hline & Lactate & GP & $\mathrm{pH}$ & Lactate & GP & $\mathrm{pH}$ & \\
\hline PM & $-0.46^{*}$ & $-0.57 * *$ & $0.19^{\mathrm{ns}}$ & $-0.49^{*}$ & $-0.54 *$ & $0.49^{*}$ & $-0.45^{*}$ \\
\hline LD & $-0.51 *$ & $-0.58 * *$ & $-0.24^{\mathrm{ns}}$ & $-0.46^{*}$ & $-0.59^{\text {ns }}$ & $0.53^{*}$ & $-0.49^{\text {ns }}$ \\
\hline
\end{tabular}

Increased $\Delta \mathrm{Ct}$ is reflective of reduced expression. $\Delta \mathrm{Ct}=$ cycles to threshold of glycogenin-1 minus $\mathrm{Ct}$ of $\beta$-actin. *Significant at the $5 \%$ level. **Significant at the $1 \%$ level. ns $=$ not significantly different $(\mathrm{P}>0.05)$. For abbreviations, see legend to Table 2.

\section{DISCUSSION}

The 2 muscles in this study, LD and PM, were chosen due to their difference in fibertype composition (Henckel et al., 1997; Gil et al., 2008). The LD is representative of a mixed fiber-type muscle, which consists of a higher proportion of type IIB fibers, while the PM has a higher proportion of type I, type IIA, and type IIX fibers. These results were in good agreement with the results of Tanabe et al. (1999). Previous studies have indicated that glycogen particles mainly accumulate in muscles containing type IIB fibers (Estrade et al., 1993; Lee et al., 2012), and compared with glycolytic muscles, oxidative muscles have a lower glycogen content and lower glycolytic potential (Hambrecht et al., 2005). Ferguson et al. (2008) suggested that a high proportion of type IIB fibers would cause a greater $\mathrm{pH}$ decline; however, the rate of $\mathrm{pH}$ decline is actually faster in muscles with more type I fibers than in muscles with more type IIB fibers. This was confirmed in the current study as $\mathrm{pH}$ at $45 \mathrm{~min}$ post-mortem in the LD was higher than that in the PM, but the overall change in $\mathrm{pH}$ was greater in the LD. In 
fact, $\mathrm{pH}$ did not change significantly in the PM between 45 min and $24 \mathrm{~h}$, which was similar to the results of Melody et al. (2004). In the present study, the lower GP of the PM relative to the LD matched results of previous studies comparing oxidative- and glycolytic-type muscles (Hambrecht et al., 2005).

In this study, the ultimate $\mathrm{pH}$ value was strongly correlated with muscle metabolites, when measured at both $45 \mathrm{~min}$ and $24 \mathrm{~h}$ post-mortem. Muscle GP is an indicator of glycogen storage and potential lactate production, and is often negatively correlated with ultimate $\mathrm{pH}$ (Hartschuh et al., 2002; Bertol et al., 2006). It has previously been shown that the metabolite content and the $\mathrm{pH}$ of post-mortem muscle influence its quality measures, including color, water-holding capacity, and tenderness loss (Huff-Lonergan et al., 2002; Gil et al., 2008). Meat with increased glycolytic potential often has poorer quality, resulting in paler, softer pork with poor water-holding capacity (Enfält et al., 1997; Hamilton et al., 2003).

The GYG protein forms the core of glycogen and its physiological function is to initiate the formation of a new glycogen granule in muscle (Whelan, 2007). Therefore, the positive correlation between GYG expression and available glycogen was to be expected. However, GYG expression was also positively correlated to the lactate content at $45 \mathrm{~min}$ and $24 \mathrm{~h}$ post-mortem, as well as to GP, suggesting an overall relationship between GYG expression and glycolysis. The expression of GYG was significantly higher in the LD than in the PM post-mortem. This difference in GYG expression may reflect an expression difference in living muscle. It is possible, however, although beyond the scope of this study, that the increase in GYG expression in the LD muscle post-mortem was concomitant with glycogenolysis. As both the PM and LD muscles experienced glycogenolysis post-mortem, it is also possible that differences in GYG expression are related to the difference in muscle fiber types between the 2 muscles. Further research relating muscle fiber type, physiological glycogen stores, and expression of GYG in living muscle is needed.

\section{CONCLUSION}

Glycogen metabolites (lactate and GP) were significantly negatively correlated with ultimate $\mathrm{pH}$ and significantly positively correlated with the $\Delta \mathrm{pH}$ from 45 min to $24 \mathrm{~h}$ postmortem. Glycogen metabolism, $\mathrm{pH}$ decline, and ultimate $\mathrm{pH}$ post-mortem may be affected by muscle fiber composition. Furthermore, the expression level of the GYG gene was related to the glycogenolysis process, and may be associated with the muscle fiber composition. Finally, the process of anaerobic metabolism of muscle glycogen had a significant impact on GP and on the ultimate $\mathrm{pH}$ of pork.

\section{ACKNOWLEDGMENTS}

Research supported by the earmarked fund for China Agriculture Research System (\#CARS-36-05B), the International Science \& Technology Cooperation Program of China (\#2011DFB30340), the Initiation Foundation Project of Chinese Education Ministry, and the Sichuan Sci \& Tech Support Program. The authors acknowledge the technical support of the Meat Science Lab, Department of Animal Science, and the W.M. Keck Center for Comparative and Functional Genomics, University of Illinois at Urbana-Champaign, USA. 


\section{REFERENCES}

Alonso MD, Lomako J, Lomako WM and Whelan WJ (1995). A new look at the biogenesis of glycogen. FASEB J. 9: 1126-1137.

Bendall JR (1973). Post Mortem Changes in Muscle. In: Structure and Function of Muscle (Bourne GH, ed.). Academic Press, New York, 243-309.

Bertol TM, Ellis M, Ritter MJ, McKeith FK, et al. (2006). Variation in glycolytic potential and fresh pork quality traits along the Longissimus dorsi of slaughter weight pigs. J. Muscle Foods 17: 237-247.

Boler DD, Dilger AC, Bidner BS, Carr SN, et al. (2010). Ultimate pH explains variation in pork quality. J. Muscle Foods 21: $119-130$

Choe JH, Choi YM, Lee SH, Shin HG, et al. (2008). The relation between glycogen, lactate content and muscle fiber type composition, and their influence on postmortem glycolytic rate and pork quality. Meat Sci. 80: 355-362.

Enfält AC, Lundström K, Hansson I, Lundeheim N, et al. (1997). Effects of outdoor rearing and sire breed (Duroc or Yorkshire) on carcass composition and sensory and technological meat quality. Meat Sci. 45: 1-15.

Estrade M, Vignon X, Rock E and Monin G (1993). Glycogen hyperaccumulation in white muscle fibres of RN- carrier pigs. A biochemical and ultrastructural study. Comp. Biochem. Physiol. B 104: 321-326.

Ferguson DM, Daly BL, Gardner GE and Tume RK (2008). Effect of glycogen concentration and form on the response to electrical stimulation and rate of post-mortem glycolysis in ovine muscle. Meat Sci. 78: 202-210.

Fernandez X and Tornberg E (1991). A review of the causes of variation in muscle glycogen content and ultimate $\mathrm{pH}$ in pigs. J. Muscle Foods 2: 209-235.

Fernandez X, Tornberg E, Naveau J, Talmant A, et al. (1992). Bimodal distribution of the muscle glycolytic potential in French and Swedish populations of hampshire crossbred pigs. J. Sci. Food Agric. 59: 307-311.

Gil M, Delday MI, Gispert M, I Furnols MF, et al. (2008). Relationships between biochemical characteristics and meat quality of Longissimus thoracis and Semimembranosus muscles in five porcine lines. Meat Sci. 80: 927-933.

Hambrecht E, Eissen JJ, Newman DJ, Smits CH, et al. (2005). Preslaughter handling effects on pork quality and glycolytic potential in two muscles differing in fiber type composition. J. Anim. Sci. 83: 900-907.

Hamilton DN, Miller KD, Ellis M, McKeith FK, et al. (2003). Relationships between longissimus glycolytic potential and swine growth performance, carcass traits, and pork quality. J. Anim. Sci. 81: 2206-2212.

Hartschuh JK, Novakofski J and McKeith FK (2002). Practical Aspects of the Glycolytic Potential Assay. In: Proceedings of the 55th Annual Reciprocal Meat Conference 39-42.

Henckel P, Oksbjerg N, Erlandsen E, Barton-Gade P, et al. (1997). Histo- and biochemical characteristics of the Longissimus dorsi muscle in pigs and their relationships to performance and meat quality. Meat Sci. 47: 311-321.

Huff-Lonergan E, Baas TJ, Malek M, Dekkers JC, et al. (2002). Correlations among selected pork quality traits. J. Anim. Sci. 80: 617-627.

Lawrie RA (1966). Metabolic Stresses Which Affect Muscle. In: Physiology and Biochemistry of Muscle as a Food (EJBRG Cassens and JC Trautman, eds.). University of Wisconsin Press, Madison, 137-164.

Lee SH, Choe JH, Choi YM, Jung KC, et al. (2012). The influence of pork quality traits and muscle fiber characteristics on the eating quality of pork from various breeds. Meat Sci. 90: 284-291.

Melody JL, Lonergan SM, Rowe LJ, Huiatt TW, et al. (2004). Early postmortem biochemical factors influence tenderness and water-holding capacity of three porcine muscles. J. Anim. Sci. 82: 1195-1205.

Monin G and Sellier P (1985). Pork of low technological quality with a normal rate of muscle $\mathrm{pH}$ fall in the immediate post-mortem period: The case of the Hampshire breed. Meat Sci. 13: 49-63.

Smythe C, Watt P and Cohen P (1990). Further studies on the role of glycogenin in glycogen biosynthesis. Eur. J. Biochem. 189: 199-204.

Tanabe R, Muroya S and Chikuni K (1999). Expression of myosin heavy chain isoforms in porcine muscles determined by multiplex PCR. J. Food Sci. 64: 222-225.

Whelan WJ (2007). Why the linkage of glycogen to glycogenin was so difficult to determine. Biochem. Mol. Biol. Educ. 35: 313-315.

Xiao RJ, Xu ZR and Chen HL (1999). Effects of ractopamine at different dietary protein levels on growth performance and carcass characteristics in finishing pigs. Anim. Feed Sci. Technol. 79: 119-127.

Ylä-Ajos MSK, Lindahl G, Young JF, Theil PK, et al. (2007). Post-mortem activity of the glycogen debranching enzyme and change in the glycogen pools in porcine $\mathrm{M}$. longissimus dorsi from carriers and non-carriers of the RN- gene. Meat. Sci. 75: 112-119. 